\title{
Algengi sykursýki og heilsufar íbúa á íslenskum hjúkrunarheimilum 2003-2012
}

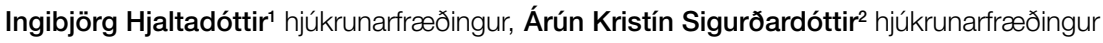

\section{ÁGRIP}

Inngangur: Sykursýki er vaxandi vandamál meðal eldra fólks og einn af áhættupáttum fyrir flutning á hjúkrunarheimili. Ennfremur er sjúkdómabyrði og lyfjanotkun peirra sem eru með sykursýki oft meiri. Tilgangur rannsóknarinnar var að skoða algengi sykursýki á íslenskum hjúkrunarheimilum yfir árin 2003-2012 og gera samanburð á heilsufari, færni, lyfjanotkun og sjúkdómsgreiningum íbúa með eða án sjúkdómsgreiningarinnar sykursýki sem bjuggu á hjúkrunarheimili árið 2012.

Efniviður og aðferð: Rannsóknin var afturskyggn og mælitækið Gagnasafn um heilsufar og hjúkrunarpörf íbúa á öldrunarstofnunum var notað við gagnasöfnun ( $N=16.169)$. Nánari tölfræðileg greining var gerð á gögnum frá 2012 ( $\mathrm{n}=2337)$.

Niðurstöður: Á rannsóknartímabilinu var meðalaldur frá 82,3 (sf 9,1) til 85,0 ár (sf 8,4) og hlutfall kvenna frá 65,5 til $68,0 \%$. Hlutfall peirra sem voru skráðir með sjúkdómsgreininguna sykursýki hækkaði úr 10,3\% árið 2003 í 14,2\% árið 2012 ( $p \leq 0,001)$. Meðalaldur íbúa með sykursýki árið 2012 var 82,7 ár en annarra 85 ár. Íbúar með sykursýki höfðu meiri húðvandamál, notuðu fleiri lyf, vitræn geta var betri og pátttaka i virkni var meiri. Peir sem voru með sykursýki voru frekar með háprýsting, hjartasjúkdóm vegna blóðpurrðar, heilaáfall, nýrnabilun, oflæti/punglyndi, sjónukvilla vegna sykursýki og aflimun, en voru síður með kvíðaröskun, Alzheimer-sjúkdóm og beingisnun.

Ályktun: Íbúar með sykursýki á hjúkrunarheimilum eru yngri en aðrir og betur á sig komnir andlega, en hins vegar getur meðferð peirra verið margslungin og hana parf að sérsníða að hverjum einstaklingi. Sykursýki er vaxandi vandi inni á hjúkrunarheimilum og pví parf að tryggja að starfsfólk hafi pekkingu á hvernig best er að meðhöndla sykursýki hjá öldruðum.
Hiúkrunarfræðideild Háskóla Íslands og flæðissviði Landspítala, ${ }^{2}$ heilbrigðisvísindasviði Háskólans á Akureyri.

Fyrirspurnir: Ingibjörg Hjaltadóttir ingihj@hi.is

Greinin barst 14. júlí 2014, sampykkt til birtingar 10. desember 2014.

\section{Inngangur}

Eldra fólki fer fjölgandi á Íslandi og pað veldur breytingu í aldurssamsetningu pjóðarinnar og pörf fyrir heilbrigðispjónustu. Meðal eldra fólks er sykursýki vaxandi vandamál ${ }^{1}$ en sykursýki eykur áhættu á að fara á hjúkrunarheimili², og 26,4\% (n=144.969) af peim sem dvöldu á hjúkrunarheimili í Bandaríkjunum árið 2002 (n=548.572), voru með sykursýki. ${ }^{3}$ Algengi sykursýki á hjúkrunarheimilum í Evrópu er frá 17,2\% ${ }^{4}$ til 19,9\% ${ }^{5}$ en í Bandaríkjunum frá $24 \%{ }^{6}$ til 32,8\%.7 Íslensk rannsókn ${ }^{8}$ fann að árin 2002-2004, notuðu 7\% íbúa hjúkrunarheimila lyf við sykursýki. Hins vegar hefur algengi sykursýki á Íslandi, meðal fólks 75-84 ára, verið áætlað um $12 \%$ meðal kvenna en um $17 \%$ hjá körlum. ${ }^{1}$

Algengi sykursýki minnkar eftir pví sem íbúar á hjúkrunarheimilum eldast og rannsókn ${ }^{7}$ sýndi að aldurshópurinn frá 65-84 ára var fremur greindur með sykursýki (40,8\%), borið saman við 85 ára og eldri (24\%). Pað er samhljóða Moore og félögum, ${ }^{6}$ en eftir pví sem íbúarnir urðu eldri dró úr sykursýki og algengi sykursýki hjá konum minnkaði hraðar en meðal karla. Í aldurshópnum 65-69 ára (n=66.676) voru 38\% kvenna með sykursýki en $11 \%$ af peim sem voru 95 ára og eldri $(\mathrm{n}=111.162)$, fyrir karlmenn voru sambærilegar tölur $34 \%$ og $16 \%$.

Fjöllyfjanotkun er áhættupáttur fyrir dvöl á hjúkrunarheimili, ${ }^{2}$ en hlutfall íbúa á hjúkrunarheimilum sem notuðu 9 lyf eða fleiri á dag jókst úr 50,8\% í 64,9\% frá 2003 til 2009.9 Erlendis nota íbúar með sykursýki fleiri lyf, eða 10,9 lyf að meðaltali, borið saman við íbúa án sykursýki, sem nota 8,4 lyf að meðaltali. ${ }^{3}$ Sambærilegar tölur fyrir íbúa með sykursýki eru ekki pekktar fyrir Ísland.

Hreyfifærni ${ }^{10}$ og vitræn geta ${ }^{11}$ ráđa miklu um vistun á hjúkrunarheimili. Líkamleg færni eldra fólks með sykursýki skerðist hraðar en peirra sem ekki hafa sykursýk $\mathrm{i}^{12,13} \mathrm{og}$ Travis og félagar ${ }^{3}$ fundu að líkamleg færni íbúa með sykursýki var minni en peirra án sykursýki, sem pó voru eldri. Íbúar með sykursýki hafa mikla pörf fyrir aðstoð við athafnir daglegs lífs, svo sem hreyfingu, fæðuinntekt og útskilnað. ${ }^{14}$ Erlendis eru verkir einnig algengari meðal íbúa með sykursýki en án hennar, ${ }^{3}$ ekki er vitað hvort slíkur munur finnst hér á landi. Hins vegar voru íbúar sem voru nýfluttir á íslensk hjúkrunarheimili á árunum 1996 til 2006 með verki og hlutfall peirra með daglega verki var frá $30-41 \% .{ }^{15}$ Borið saman við fólk án sykursýki, eru íbúar með sykursýki á öldrunarheimilum greindir með fleiri sjúkdóma ${ }^{3,7}$ og eru alvarlega veikir., ${ }^{3,14}$ Lítið er vitað um algengi sykursýki á íslenskum hjúkrunarheimilum og hvernig heilsufar og færni íbúa með sykursýki er samanborið við íbúa án sykursýki. Pó má ætla að íbúar með sykursýki purfi meiri umönnun en fólk án sykursýki. 
Tafla I. Fjöldi greininga með RAI-mælitækinu eftir árum, meðalaldur og hlutfall kvenna.

\begin{tabular}{lcccc}
\hline Ár & $\mathrm{N}$ & $\%$ & Meðalaldur (sf) & Konur n (\%) \\
\hline 2003 & 447 & 2,8 & $82,3(9,1)$ & $293(65,5)$ \\
\hline 2004 & 1001 & 6,2 & $82,8(8,5)$ & $677(67,6)$ \\
\hline 2005 & 1383 & 8,6 & $83,4(8,2)$ & $922(66,7)$ \\
\hline 2006 & 1721 & 10,6 & $84,4(7,9)$ & $1149(66,8)$ \\
\hline 2007 & 1922 & 11,9 & $84,4(7,9)$ & $1268(66,0)$ \\
\hline 2008 & 1885 & 11,7 & $84,7(8,2)$ & $1247(66,2)$ \\
\hline 2009 & 1867 & 11,5 & $84,9(8,2)$ & $1223(65,5)$ \\
\hline 2010 & 1754 & 10,8 & $85,0(8,4)$ & $1192(68,0)$ \\
\hline 2011 & 1852 & 11,5 & $84,5(8,6)$ & $1232(66,5)$ \\
\hline 2012 & 2337 & 14,5 & $84,7(8,2)$ & $1531(65,5)$ \\
\hline Samtals & 16169 & 100 & $84,2(8,4)$ & $11.294(66,3)$ \\
\hline
\end{tabular}

Tilgangur rannsóknarinnar var að skoða algengi sykursýki á íslenskum hjúkrunarheimilum yfir árin 2003-2012. Einnig að gera samanburð á heilsufari, færni, lyfjanotkun og sjúkdómsgreiningum íbúa með eða án sjúkdómsgreiningarinnar sykursýki sem bjuggu á hjúkrunarheimili árið 2012.

\section{Efniviður og aðferð}

Mælitækið sem notað var við gagnasöfnun var Gagnasafn um heilsufar og hjúkrunarpörf íbúa á öldrunarstofnunum, útgáfa 2.0 (Minimum Data Set 2.0) sem er gagnasöfnunarhlutinn af matstækinu Raunverulegur aðbúnaður íbúa (Resident Assessment Instrument; RAI). Gagnasafnið er pó aðeins partur af RAI-matstækinu og verður vísað til pess sem RAI-mælitækis í pessari umfjöllun. Í RAI-mælitækið eru skráðar upplýsingar um heilsufar, færni og parfir íbúa á hjúkrunarheimilum. Frá árinu 1996 hafa íbúar á íslenskum hjúkrunarheimilum verið metnir með RAI-mati og frá árinu 2003 hefur pað verið gert að minnsta kosti prisvar á ári. ${ }^{16}$

RAI-mælitækið inniheldur um 350 breytur og var fyrst og fremst hannað sem klínískt mælitæki til að bæta umönnun en hefur einnig verið notað við gagnasöfnun fyrir rannsóknir víða um heim. Mælitækið hefur reynst gagnlegt við alpjóðlegan samanburð og rannsóknir hafa sýnt fram á réttmæti og áreiðanleika pess. ${ }^{17}$ Hjúkrunarfræðingur sem hefur lært á mælitækið hefur yfirumsjón með gerð matsins ásamt lækni, sjúkrapjálfara, iðjupjálfa og sjúkraliða. Nákvæm leiðbeiningabók sem skilgreinir hvernig meta á hvert atriði styður við framkvæmd matsins en upplýsinga fyrir matið er aflað úr sjúkraskrá, með athugun á íbúanum og viðtali við íbúa og ættingja hans. Í pessari rannsókn eru notaðar valdar breytur úr RAI-mælitækinu auk útkomu úr 6 kvörðum sem hannaðir hafa verið fyrir mælitækið og nota má til að skoða breytingu á færni og heilsufari yfir tíma.

Lífskvarðinn hefur gildi frá 0 til 5. Lægsta gildið 0 gefur til kynna að heilsufar einstaklingsins sé stöðugt en hæsta gildið 5 að heilsufar sé óstöðugt, hætta sé á andláti, sjúkrahússinnlögn og miklu álagi á umönnunaraðila. Rannsóknir hafa staðfest að kvarðinn hefur forspárgildi fyrir andlát. ${ }^{17,18}$

Verkjakvarðinn hefur gildi á bilinu 0 til 3. Gildið 0 merkir að einstaklingurinn hefur enga verki en hæsta gildið 3 að um mjög mikla og óbærilega verki sé að ræða. Niðurstöður rannsakenda hafa bent

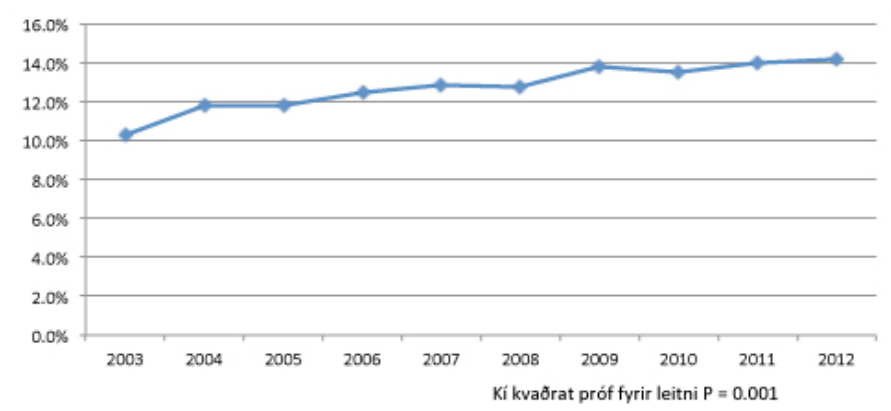

Mynd 1. Hlutfall íbúa á íslenskum hjúkrunarheimilum með sykursýki á árunum 20032012.

til að kvarðinn sé áreiðanlegur til að meta verki hjá íbúum á hjúkrunarheimilum. ${ }^{19}$

Punglyndiskvarðinn hefur lægsta gildi 0 sem gefur til kynna að einstaklingurinn hafi engin einkenni punglyndis. Gildi 3 bendir til vægs punglyndis og gildi 14, sem er hæsta gildi kvarðans, að um mjög alvarlegt punglyndi sé að ræða. ${ }^{20}$ Rannsakendur hafa bent á að pörf sé á frekari rannsóknum á kvarðanum, en að kvarðinn sýni mjög gott næmi og viðunandi sérhæfni. ${ }^{20}$

Vitræni kvarðinn hefur sýnt ágæta fylgni við MMSE (Mini-Mental State Examination) við mat á vitrænni getu. Gildið 0 pýðir að einstaklingurinn hefur óskerta vitræna getu en síðan versnandi vitræna getu með hækkandi gildum og hæsta gildið 6 gefur til kynna mjög mikla vitræna skerðingu. ${ }^{21}$

Langi ADL-kvarðinn sýnir færni einstaklingsins í athöfnum daglegs lífs (ADL) og hefur gildi á bilinu 0 til 28. Hækkandi gildi benda til versnandi færni í ADL og hafa athuganir bent til næmi kvarðans við breytingar á færni. ${ }^{17}$

Virknikvarðinn hefur gildi frá 0 til 6 og gefur til kynna meiri virkni eftir pví sem talan er hærri. Núll merkir að einstaklingurinn hefur dregið sig í hlé frá félagslegum samskiptum en hæsta gildið 6 gefur til kynna mikið frumkvæði og pátttöku í félagslegum athöfnum. Gildin 0-2 hafa verið tengd lítilli félagslegri virkni í samanburði við pá sem hafa gildi á bilinu 3-6.22

\section{Úrtak}

Gögnin sem notuð voru í rannsókninni var mat gert á íbúum á íslenskum hjúkrunarheimilum með RAI-mælitækinu yfir árabilið 2003-2012 (N=16.169). Notað var nýjasta mat hvers einstaklings fyrir hvert ár, en mat gert við fyrstu komu eða eftir nýlega endurkomu voru ekki notuð. Petta var gert til að varpa ljósi á heilsufarspætti sem tengdust meðferð á hjúkrunarheimilinu. Í samanburði á milli ára er pví um blandaða hópa að ræða og sami einstaklingur getur átt mat í gögnum frá einu eða fleiri árum.

\section{Tölfræði}

Lýsandi og greinandi tölfræði var notuð til að greina gögnin. Fyrir stikalaus gögn, raðbreytur og nafnbreytur var notað Pearson Kíkvaðrat próf og „Yates Continuity Correction“ notuð pegar um 2x2 töflur var að ræða. Við athugun á leitni yfir mörg ár var notað Kíkvaðrat próf fyrir leitni. T-próf milli óháðra hópa var notað fyrir 
Tafla II. Kyn, aldur, heilsufar, færni og lyfjanotkun íbúa sem dvöldu á íslenskum hjúkrunarheimilum árið 2012 eftir pví hvort peir voru með sykursýki eđa ekki.

\begin{tabular}{|c|c|c|c|}
\hline & $\begin{array}{c}\text { Með } \\
\text { sykursýki }\end{array}$ & $\begin{array}{l}\text { Ekki med } \\
\text { sykursýki }\end{array}$ & $\mathrm{P}$ \\
\hline $\mathrm{N}=2337 \mathrm{n}(\%)$ & $332(14,2)$ & $2005(85,8)$ & \\
\hline Konur (\%) & $204(61,4)$ & $1327(66,2)$ & $0,105^{\star}$ \\
\hline Meðalaldur (sf) & $82,7(7,9)$ & $85(8,2)$ & $<0,001^{\star *}$ \\
\hline Meðallíkamspyngdarstuðull (sf) & $27,1(5,5)$ & $24,7(5,9)$ & $<0,001^{\star *}$ \\
\hline \multicolumn{4}{|c|}{ Heilsufar og færni samkvæmt kvörðum, meðaltal (sf) } \\
\hline Lífskvarði & $2,02(1,42)$ & $2,02(1,38)$ & $0,950^{\star *}$ \\
\hline Verkjakvarði & $1,15(0,97)$ & $1,11(0,96)$ & $0,510^{\star *}$ \\
\hline Punglyndiskvarði & $2,71(3,35)$ & $2,89(3,28)$ & $0,370^{\star *}$ \\
\hline Vitrænn kvarði & $3,11(1,80)$ & $3,45(1,79)$ & $0,001^{\star \star}$ \\
\hline Langur ADL-kvarði & $16,32(8,75)$ & $17,07(8,34)$ & $0,128^{\star *}$ \\
\hline Virknikvarði & $2,86(2,06)$ & $2,51(2,04)$ & $0,004^{\star *}$ \\
\hline \multicolumn{4}{|l|}{ Sýkingar n (\%) } \\
\hline Pvagfærasýking & $59(17,8)$ & $257(12,8)$ & $0,018^{\star}$ \\
\hline Sýking í sári & $10(3,0)$ & $52(2,6)$ & $0,799^{*}$ \\
\hline Lungnabólga & $13(3,9)$ & $89(4,4)$ & $0,774^{*}$ \\
\hline Sýking í öndunarvegi & $15(4,5)$ & $72(3,6)$ & $0,503^{*}$ \\
\hline \multicolumn{4}{|l|}{ Húð og sár n (\%) } \\
\hline Útbrot á húð & $139(41,6)$ & $685(34,2)$ & $0,011^{*}$ \\
\hline Skert tilfinning í húð & $112(33,7)$ & $490(24,4)$ & $<0,001^{*}$ \\
\hline Prýstingssár, stig 1-4 & $70(21,1)$ & $345(17,2)$ & $0,102^{*}$ \\
\hline Prýstingssár, stig 1 & $36(10,8)$ & $198(9,9)$ & $0,656^{\star}$ \\
\hline Prýstingssár, stig 2 & $40(12,0)$ & $180(9,0)$ & $0,094^{*}$ \\
\hline Prýstingssár, stig 3 & $7(2,1)$ & $13(0,6)$ & $0,019^{*}$ \\
\hline Prýstingssár, stig 4 & $2(0,6)$ & $6(0,3)$ & $0,712^{*}$ \\
\hline \multicolumn{4}{|l|}{ Lyfjanotkun \% (n) } \\
\hline Meðalfjöldi lyfja (sf) & $11,5(4,23)$ & $9,6(4,15)$ & $<0,001^{\star *}$ \\
\hline Svefnlyf (NO5C) & $48,5(161)$ & $48,2(967)$ & $0,976^{*}$ \\
\hline Geðdeyfðarlyf (NO6A) & $53,6(178)$ & $55,1(1105)$ & $0,654^{*}$ \\
\hline Kvíðastillandi lyf (NO5B) & $28,6(95)$ & $31,5(631)$ & $0,328^{*}$ \\
\hline Sterk geðlyf (NO5A) & $25,0(83)$ & $27,2(546)$ & $0,434^{*}$ \\
\hline Notkun á 9 eða fleiri lyfjum & $255(76,8)$ & $1150(57,4)$ & $<0,001^{*}$ \\
\hline
\end{tabular}

*Kí-kvaðrat próf; **T próf milli óháđra hópa

stikabundin gögn. Við alla greiningu voru notuð marktektarmörk með $\mathrm{p}$ gildi $\leq 0,05$. Gögnin voru greind með tölfræðiforritinu SPSS útgáfu 20. Persónuvernd, vísindasiðanefnd og Embætti landlæknis veittu leyfi fyrir rannsókninni.

\section{Niðurstödur}

Lýðfræðilegar upplýsingar um heildarúrtakið ( $\mathrm{N}=16.169)$ eru sýndar í töflu I. Yfir tímabilið 2003-2012 var meðalaldur frá 82,3 ár (sf 9,1) til 85,0 ár (sf 8,4) og hlutfall kvenna frá 65,5 til 68,0\%. Hlutfall peirra sem voru skráðir með sjúkdómsgreininguna sykursýki hækkaði úr 10,3\% árið 2003 í 14,2\% árið 2012 (p\0,001) og á árabilinu 2006 til 2012, pegar úrtakið var orðið fjölmennara, hækkaði hlutfallið úr 12,4\% í 14,2\% (p=0,042) sjá mynd 1 .

Í úrtakinu frá 2012 (n=2337) var meðalaldur hópsins sem var með sykursýki marktækt lægri (82,7 ár) en hinna og með hærri

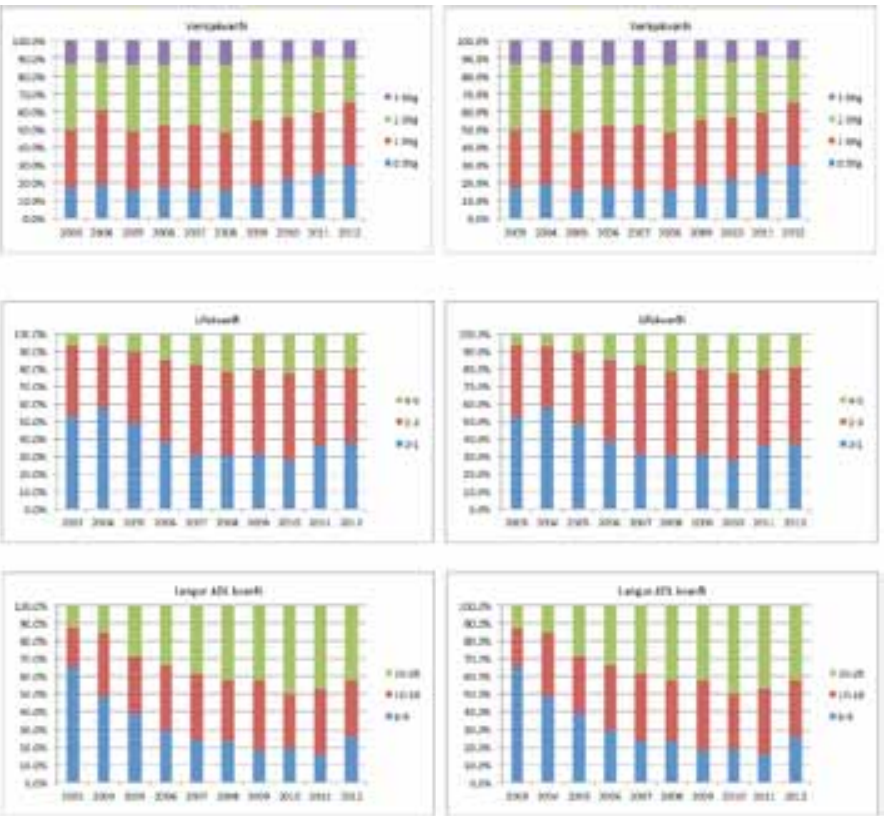

Mynd 2. Hlutfall íbúa með sykursýki eftir árum og eftir stigi á eftirfarandi kvörðum. Lífskvarði (0: lítil áhætta; 5: mikil áhætta): Verkjakvarði (0: enginn verkur; 3: óbærilegir verkir); Punglyndiskvarði (0: ekki punglyndi; 14: mikið punglyndi); Vitrænn kvarði (0: engin vitræn skerðing; 6: mikil skerðing); Langur ADL-kvarði (0: engin færni skerðing; 28: mikil færni skerðing); Virknikvarði (0: engin félagsleg virkni; 6: mikil félagsleg virkni).

líkamspyngdarstuðul eða 27,1 að meðaltali (sjá töflu II). Af heildarúrtakinu árið 2012, höfðu 23,1\% íbúanna komið á hjúkrunarheimilið frá bráðaspítala eða endurhæfingardeild og 52,6\% komu frá eigin heimili. Af peim sem komu frá eigin heimili höfðu 29,1\% ekki notið aðstoðar heimahjúkrunar eða heimapjónustu fyrir flutning á hjúkrunarheimili.

Próun heilsufars og færni íbúa með sykursýki yfir árin 20032012 er sýnd á mynd 2. Par sést að heilsufari og færni íbúa með sykursýki hefur almennt heldur hrakað á peim 10 árum sem myndin nær yfir, par sem fleiri eru með hærri gildi á langa ADLkvarðanum $(p \leq 0,001)$, Vitræna kvarðanum $(p \leq 0,001)$ og Lífskvarðanum $(p \leq 0,001)$. Pó eru heldur færi með verki af stigi $2(p \leq 0,001)$ en ekki sjást miklar breytingar á mæligildum annarra kvarða.

Gögn frá árinu 2012 sýndu að vitræn geta peirra sem voru með sykursýki var betri en annarra íbúa $(\mathrm{p} \leq 0,001)$ og peir tóku meiri pátt í virkni en aðrir samkvæmt Virknikvarða $(p=0,004)$, en annar munur kom ekki fram milli hópanna samkvæmt kvörðunum (sjá töflu II). Ekki var heldur marktækur munur á pví hvort íbúar væru með bráðasjúkdómseinkenni eða voru metnir eiga 6 mánuði eða skemur eftir ólifaða, eftir pví hvort peir voru með sykursýki eða ekki. Athugun á byltum eða beinbrotum eftir pví hvort íbúar voru með sykursýki eða ekki, sýndi heldur ekki marktækan mun. Verkjakvarði gaf ekki til kynna að munur væri á hópunum varðandi verki og athugun á styrkleika verkja (stig 0-3) eða staðsetningu verkja eftir pví hvort íbúar voru með sykursýki eða ekki, sýndi heldur ekki mun. Marktækt fleiri með sykursýki voru með pvagsýkingar (tafla II) pó ekki væri marktækur munur milli hópa á pvag- eða hægðaleka. Meira var um útbrot á húð (41,6\%) og skerta tilfinningu í húð (33,7\%) hjá peim íbúum sem voru með sykursýki og dvöldu á hjúkrunarheimili árið 2012 en öðrum íbúum. Einnig var meira um prýstingssár af stigi 3 (2,1\%) en hjá öðrum íbúum (sjá 
Tafla III. Algengi sjúkdómsgreininga hjá íbúum á hjúkrunarheimilum eftir pví hvort peir voru með sykursýki eđa ekki árið 2012.

\begin{tabular}{|c|c|c|c|}
\hline & $\begin{array}{l}\text { Með sykursýki } \\
\mathrm{n}(\%)\end{array}$ & $\begin{array}{c}\text { Ekki með } \\
\text { sykursýki n (\%) }\end{array}$ & $\mathrm{P}^{*}$ \\
\hline Háprýstingur & $230(69,3)$ & $1111(55,4)$ & $<0,001$ \\
\hline Gigt - liðbólgur & $165(49,7)$ & $1047(52,2)$ & 0,428 \\
\hline Punglyndi & $142(42,8)$ & $919(45,8)$ & 0,327 \\
\hline $\begin{array}{l}\text { Hjartasjúkdómar vegna } \\
\text { blóðpurrðar }\end{array}$ & $124(37,3)$ & $574(28,6)$ & 0,002 \\
\hline $\begin{array}{l}\text { Elliglöp önnur en } \\
\text { Alzheimer-sjúkdómur }\end{array}$ & $118(35,5)$ & $714(35,6)$ & 1 \\
\hline Kvíðaröskun & $110(33,1)$ & $797(39,8)$ & 0,026 \\
\hline Heilaáfall & $89(26,8)$ & $392(19,6)$ & 0,003 \\
\hline Hjartsláttartruflanir & $75(22,6)$ & $497(24,8)$ & 0,427 \\
\hline Hjartabilun & $73(22,0)$ & $367(18,3)$ & 0,13 \\
\hline Alzheimer-sjúkdómur & $64(19,3)$ & $582(29,0)$ & $<0,001$ \\
\hline Beingisnun & $62(18,7)$ & $567(28,3)$ & $<0,001$ \\
\hline Ský á auga & $53(16,0)$ & $323(16,1)$ & 1 \\
\hline Nýrnabilun & $48(14,5)$ & $153(7,6)$ & $<0,001$ \\
\hline $\begin{array}{l}\text { Ađrir hjarta-/ } \\
\text { æðasjúkdómar }\end{array}$ & $47(14,2)$ & $295(14,7)$ & 0,856 \\
\hline Útæðasjúkdómar & $26(7,8)$ & $143(7,1)$ & 0,733 \\
\hline Oflæti/punglyndi & $26(7,8)$ & $91(4,5)$ & 0,016 \\
\hline $\begin{array}{l}\text { Sjónukvilli vegna } \\
\text { sykursýki (retinopathy) }\end{array}$ & $25(7,5)$ & $2(0,1)$ & $<0,001$ \\
\hline $\begin{array}{l}\text { Skammvinnt } \\
\text { blóðpurrðarkast (TIA) }\end{array}$ & $16(4,8)$ & $119(5,9)$ & 0,496 \\
\hline Aflimun & $6(1,8)$ & $11(0,5)$ & 0,031 \\
\hline Lágprýstingur & $5(1,5)$ & $74(3,7)$ & 0,061 \\
\hline
\end{tabular}

* Kí-kvaðrat próf

töflu II). Peir íbúar sem voru með sykursýki notuðu að meðaltali 11,5 lyf sem var meira en hjá öðrum íbúum og hlutfall peirra sem notuðu 9 eða fleiri tegundir af lyfjum var einnig hærra, eða $76,8 \%$.

Algengustu sjúkdómsgreiningar peirra sem voru með sykursýki reyndust vera háprýstingur (69,3\%), gigt og liðbólgur (49,7\%), punglyndi (42,8\%), hjartasjúkdómar vegna blóðpurrðar (37,3\%) og elliglöp önnur en Alzheimer-sjúkdómur (35,5\%). Samanburður á milli peirra sem voru með sykursýki og hinna voru ekki með sykursýki sýndi að hærra hlutfall íbúa með sykursýki reyndist vera með sjúkdómsgreiningarnar háprýstingur, hjartasjúkdómar vegna blóðpurrðar, heilaáfall, nýrnabilun, oflæti/punglyndi, sjónukvilli vegna sykursýki og aflimun, (tafla III). Sjúkdómsgreiningar sem reyndust tíðari meðal peirra sem ekki voru með sykursýki voru kvíðaröskun, Alzheimer-sjúkdómur og beingisnun.

\section{Umræður}

Helstu niðurstöður pessarar rannsóknar eru að hlutfall íbúa á hjúkrunarheimilum sem eru með sjúkdómsgreininguna sykursýki hefur hækkað á 10 árum um rúm 4\%. Petta er slæm próun par sem íbúar með sykursýki eru oftar pyngri í umönnun en aðrir. Pó ekki hafi komið fram munur milli hópa á ADL-kvarða, voru peir með sykursýki yngri, með hærri líkamspyngdarstuðul og höfðu fleiri vandamál sem vitað er að tengjast seinkvillum sykursýki, svo sem hjartasjúkdóma, nýrnabilun og prýstingssár á alvarlegum stigum. Brýnt er að reynt sé að koma í veg fyrir próun á sykursýki af tegund 2, hvenær sem er á æviskeiði einstaklingsins, en vitað er að hár líkamspyngdarstuðull hefur fylgni við sykursýki 2. ${ }^{1}$ Könnun Embættis landlæknis á „Heilsu og líðan Íslendinga árið 2012“ sýndi að 63,3\% pátttakenda sögðu að líkamspyngdarstuðull peirra væri $\geq 26^{23}$ og rannsókn ${ }^{1}$ úr gögnum Hjartaverndar staðfesti að meðallíkamspyngdarstuðull hækkaði um tvær einingar hjá báðum kynjum yfir tímabilið 1967 til 2007. Pví má búast við að auknar lífslíkur ásamt fleira fólki með sykursýki munu auka álag á öldrunarpjónustu í framtíðinni. Vitundarvakning parf að eiga sér stað á Íslandi til að finna leiðir til að draga úr ofpyngd og offitu, par parf að ná til almennings og fá matvælaiðnaðinn til að auka framboð á hollum mat og skyndibita.

Hér kom fram að íbúar með sykursýki voru yngri en peir án sykursýki, og er pað í samræmi við niðurstöður erlendra rannsókna ${ }^{3,24}$ en í rannsókn Resnick og félaga ${ }^{24}(n=13,507)$ voru peir með sykursýki 81,7 ára á móti 84,9 árum peirra án sykursýki. Íslensk langtímarannsókn ${ }^{25}$ staðfestir að fólk með sykursýki af tegund 2 hafi skertar lífslíkur í samanburði við aðra og getur pað skýrt hvers vegna meðalaldur fólks með sykursýki er lægri en hinna á hjúkrunarheimilum hér á landi. Ef hægt er að fækka peim sem próa með sér sykursýki af tegund 2, er möguleiki að fækka yngri íbúum á öldrunarstofnunum. Eldra fólk vill dvelja á eigin heimili sem lengst ${ }^{26}$ og hvert ár sem einstaklingur dvelur á hjúkrunarheimili er dýrt fyrir samfélagið, enda greiðir ríkið tæplega 9 milljónir á ári fyrir hvern einstakling á hjúkrunarheimili. ${ }^{16}$

Líkamspyngdarstuðull íbúa með sykursýki var hærri en hinna, sem samræmist öðrum rannsóknum. ${ }^{7}$ Sýnt hefur verið að bæði lágur og hár líkamspyngdarstuðull tengist aukinni áhættu á dauðsföllum. ${ }^{27}$

Engin munur kom fram á ADL-færni íbúa sem voru með sykursýki og hinna, sem er í samræmi við niðurstöður Dybicz og félaga ${ }^{7}$ en í mótsögn við rannsókn Travis og félaga ${ }^{3}$, en par voru íbúar með sykursýki með lakari getu til að sjá um athafnir daglegs lífs en hinir. Hér reyndust íbúar með sykursýki hafa betri vitræna getu en hinir, sem samræmist niðurstöðum Travis og félaga ${ }^{3}$ en aðrir hafa ekki fundið marktækan mun á vitrænni getu íbúa með eða án sykursýki.7 Á Íslandi virðast íbúar með sykursýki fremur fá pláss á öldrunarheimilum vegna líkamlegrar færniskerðingar en vegna vitrænnar skerðingar. Seinkvillar sykursýki próast yfir mörg ár og brýnt er að meðferð sykursýki fylgi klínískum leiðbeiningum til að letja framkomu seinkvilla. ${ }^{27}$

Hér voru 21,1\% íbúa með sykursýki skráðir með prýstingssár á stigi 1-4 og 17,2\% peirra án sykursýki. Petta er svipað hlutfall og í rannsókn Travis og félaga ${ }^{3}$ sem notuðu sama mælitækið en par voru $22,9 \%$ peirra með sykursýki með prýstingssár en 16\% peirra án sykursýki. Hlutfall íbúa með prýstingssár sýnir að bæta má umönnun íbúa til að koma í veg fyrir prýstingssár og pó sérstaklega alvarlegri prýstingssár. Pau valda íbúum vanlíðan og aukinni umönnunarbyrði og kostnaði fyrir viðkomandi hjúkrunarheimili. Niðurstöður rannsóknarinnar sýndu að bæta má verkjameðferð hjá íbúum með sykursýki, par sem aðeins 16-30\% voru verkjalausir árin 2003-2012 og um 10\% voru með mikla eða óbærilega verki, sem er of hátt hlutfall. 
Íbúar með sykursýki notuðu fleiri lyf en hinir, sem samræmist erlendum rannsóknum. Í rannsókn Resnick og félaga ${ }^{24}$ notuðu íbúar með sykursýki að meðaltali 10,3 lyf en peir án sykursýki 8,4 lyf, en í pessari rannsókn voru tölurnar heldur hærri (11,5 með sykursýki; 9,6 án sykursýki). Mikil lyfjanotkun og mögulegar milliverkanir lyfja eru áhyggjuefni enda sýnt að með pví að fækka lyfjum hjá íbúum á hjúkrunarheimilum er hægt að auka lífsgæði peirra, lækka dánartíðni, fækka ferðum á bráðamóttöku ${ }^{28}$ og innlögnum á sjúkrahús. ${ }^{29}$ Íslensk rannsókn hefur einnig sýnt hækkandi hlutfall íbúa á hjúkrunarheimilum sem nota 9 eða fleiri lyf, eða úr 51\% í 65\% (2003-2009) en petta hlutfall er pó enn hærra fyrir pá sem eru með sykursýki í pessari rannsókn, eða 76,8\%. Gæðaviðmið sem notuð eru fyrir RAI-gæðavísa á íslenskum hjúkrunarheimilum mæla með pví að hlutfall íbúa sem eru á 9 eða fleiri lyfjum fari ekki upp fyrir 62,9\%. Samkvæmt gæðaviðmiðinu er pví ástæða til að skoða hvort hægt sé að endurskoða lyfjagjöf pessa hóps.

Pó ekki væri munur milli hópa á beinbrotum eða byltum var beingisnun óalgengari hjá fólki með sykursýki en peirra án sykursýki og samræmist pað niðurstöðum úr samantektargrein Hofbauer og félaga ${ }^{30}$ Par kemur einnig fram að pótt fólk með sykursýki af tegund 2 sé með minni beingisnun sé pað í meiri hættu á beinbrotum en samanburðarhópar, oft vegna aukinnar hættu á föllum. Íbúar með sykursýki pjáđust fremur en íbúar án sykursýki af hjarta- og æðasjúkdómum, sem samræmist niðurstöðum úr öðrum rannsóknum. 3,7,24

Athyglisvert er að hér var oflæti/punglyndi (geðhvörf) algengara hjá íbúum með sykursýki en hinum. Ekki fundust aðrar rannsóknir um petta efni. Hins vegar kom ekki fram munur á algengi punglyndis hjá íbúum með og án sykursýki, sem samræmist niðurstöðum Dybicz og félaga ${ }^{7}$ en ekki Travis og félaga ${ }^{3}$ par sem íbúar með sykursýki voru fremur með punglyndi en hinir.

Styrkur pessarar rannsóknar er að um er að ræða gögn frá öllum hjúkrunarheimilum á Íslandi yfir langt tímabil. Um 2500 einstaklingar búa á hjúkrunarheimilum og við túlkun gagnanna verður að hafa í huga að úrtakið frá árunum 2003-2005 er ekki stórt og pað er ekki fyrr en árið 2006 sem fjöldi í úrtaki fer yfir 1700. Frá árinu 2003 var farið að taka mið af RAI-mati við greiðslur ríkisins til hjúkrunarheimila og jókst pá notkun mælitækisins. Рað sem einnig getur valdið pví að íbúar á hjúkrunarheimilum eru ekki metnir með RAI-mælitæki er að peir látast áður en mat fer fram eða að peir flytja á hjúkrunarheimilið svo seint á viðkomandi ári að ekki næst að gera RAI-mat. Hér er um að ræða klínísk gögn en ekki rannsóknargögn en pað getur skert áreiðanleika gagnanna. Pó hefur verið bent á að gögn sem fengin eru með RAI-mælitækinu eru mikilvæg rannsóknargögn ${ }^{31}$ og sem rannsóknarmælitæki pá hafi matið sýnt sig að vera með miðlungs til mikinn áreiðanleika. ${ }^{17}$ Jafnframt hafa próffræðilegir eiginleikar kvarða peirra sem hannaðir hafa verið fyrir mælitækið bent til notagildis peirra í rannsóknum.

Upplýsingar um sjúkdómsgreiningar eru fengnar úr sjúkraskrá eða úr RAI-mælitækinu par sem læknir viðkomandi einstaklings hafði skráð pær, og pví verður að gera ráð fyrir að upplýsingar um sjúkdómsgreiningar séu misvel skráðar. Einnig takmarkast gögnin við pær breytur sem eru í mælitækinu og par er ekki gerður greinarmunur á sykursýki af tegund 1 og tegund 2, né eru nægilega miklar upplýsingar um meðferð sykursýkinnar, svo sem um blóðsykurmælingar eða hvort blóðsykurföll séu tilgreind. Pví er mikilvægt í ljósi pessara niðurstaðna að skoða frekar hversu stórt hlutfall íbúa parf á insúlínmeðferð að halda og hvernig annarri lyfjameðferð, mataræði og umönnun íbúa með sykursýki er háttað.

\section{Ályktun}

Bættar lífslíkur ásamt aukinni ofpyngd almennings á Íslandi munu líklega leiða til pess að algengi sykursýki á hjúkrunarheimilum muni halda áfram að aukast í framtíðinni. Íbúar með sykursýki eru pungir í umönnun par sem líkamleg heilsa peirra er lakari en jafnaldra. Einnig er fjöllyfjanotkun algeng meðal peirra en fjöllyfjanotkun eykur hættu á milliverkunum lyfja. Umönnun fólks með sykursýki á hjúkrunarheimilum er margslungin og hana parf að sérsníða að hverjum einstaklingi. Iðulega purfa starfsmenn að fylgjast með einkennum sykursýkinnar hjá íbúum og pví parf starfsfólk að hafa pekkingu á meðferð sykursýkinnar hjá hverjum íbúa. Pörf er á rannsóknum par sem skoðuð er meðferð og skráning upplýsinga um sykursýki meðal íbúa öldrunarheimila.

\section{pakkir}

Rannsakendur vilja pakka styrk til rannsóknarinnar frá Vísindasjóði Félags íslenskra hjúkrunarfræðinga. 


\section{Heimildir}

1. Pórsson B, Aspelund T, Harris TB, Launer LJ, Guðnason V. Próun holdafars og sykursýki í 40 ár á Íslandi Læknablaðið 2013; 95: 259-65.

2. Luppa M, Luck T, Weyerer S, Konig HH, Brahler E, RiedelHeller SG. Prediction of institutionalization in the elderly. A systematic review. Age Ageing 2010; 39: 31-8.

3. Travis SS, Buchanan RJ, Wang S, Kim M. Analyses of nursing home residents with diabetes at admission. J Am Med Dir Assoc 2004; 5: 320-7.

4. Achterberg WP, Gambassi G, Finne-Soveri H, Liperoti R, Noro A, Frijters DH. et al. Pain in European long-term care facilities: cross-national study in Finland, Italy and The Netherlands. Pain 2010; 148: 70-4.

5. Aspray TJ, Nesbit K, Cassidy TP, Farrow E, Hawthorne G. Diabetes in British nursing and residential homes: a pragmatic screening study. Diabetes Care 2006; 29: 707-8.

6. Moore KL, Boscardin WJ, Steinman MA, Schwartz JB. Age and sex variation in prevalence of chronic medical conditions in older residents of U.S. nursing homes. J Am Geriatr Soc 2012; 60: 756-64.

7. Dybicz SB, Thompson S, Molotsky S, Stuart B. Prevalence of diabetes and the burden of comorbid conditions among elderly nursing home residents. Am J Geriatr Pharmacother 2011; 9: 212-23.

8. Hansdóttir H, Guðmannsson PG. Lyfjanotkun á hjúkrunarheimilum á Íslandi 2002-2004. Lýsandi rannsókn Læknablaðið 2013; 99: 383-6.

9. Hjaltadottir I, Ekwall AK, Nyberg P, Hallberg IR Quality of care in Icelandic nursing homes measured with Minimum Data Set quality indicators: retrospective analysis of nursing home data over 7 years. Int J Nurs Stud 2012;49: 1342-53.

10. Ingimarsson $\mathrm{O}$, Aspelund $\mathrm{T}$, Jonsson PV. Vistunarmat aldraðra á árunum 1992-3001, tengsl við lifun og vistun Læknablaðið 2004; 90: 121-9.

11. Ingimarsson $\mathrm{O}$, Aspelund $\mathrm{T}$, Jonsson PV. Birtingarmynd heilabilunar í vistunarmati aldraðra fyrir hjúkrunarrými 1992-2001. Læknablaðið 2004; 90: 767-73.
12. Yau CK, Eng C, Cenzer IS, Boscardin WJ, Rice-Trumble K, Lee SJ. Glycosylated hemoglobin and functional decline in community-dwelling nursing home-eligible elderly adults with diabetes mellitus. J Am Geriatr Soc 2012; 60: 1215-21.

13. Gregg EW, Mangione CM, Cauley JA, Thompson TJ, Schwartz AV, Ensrud KE, et al. Diabetes and incidence of functional disability in older women. Diabetes Care 2002; 25: 61-7.

14. Gadsby R, Barker P, Sinclair A. People living with diabetes resident in nursing homes--assessing levels of disability and nursing needs. Diabet Med 2011; 28: 778-80.

15. Hjaltadottir I, Hallberg IR, Ekwall AK, Nyberg P. Health status and functional profile at admission of nursing home residents in Iceland over 11-year period. Int J Older People Nurs 2012; 7: 177-87.

16. Velferðarráðuneytið. Greiðslur fyrir búsetu á dvalar- og hjúkrunarheimilum. 2014; velferdarraduneyti.is/frettirvel/nr/33334 - júní 2014

17. Mor V, Intrator O, Unruh MA, Cai S. Temporal and Geographic variation in the validity and internal consistency of the Nursing Home Resident Assessment Minimum Data Set 2.0. BMC Health Serv Res 2011; 11: 78.

18. Hjaltadottir I, Hallberg IR, Ekwall AK, Nyberg P. Predicting mortality of residents at admission to nursing home: A longitudinal cohort study. BMC Health Serv Res 2011; $11: 86$.

19. Fries BE, Simon SE, Morris JN, Flodstrom C, Bookstein FL. Pain in U.S. nursing homes: validating a pain scale for the minimum data set. Gerontologist 2001; 41: 173-9.

20. Burrows AB, Morris JN, Simon SE, Hirdes JP, Phillips C. Development of a minimum data set-based depression rating scale for use in nursing homes. Age Ageing 2000; 29: 165-72.

21. Gruber-Baldini AL, Zimmerman SI, Mortimore E, Magaziner J. The validity of the minimum data set in measuring the cognitive impairment of persons admitted to nursing homes. J Am Geriatr Soc 2000; 48: 1601-6.
22. Resnick HE, Fries BE, Verbrugge LM. Windows to their world: the effect of sensory impairments on social engagement and activity time in nursing home residents. J Gerontol; Series B, Psychol Sci Soc Sci 1997; 52: 135-44.

23. Guðlaugsson JÓ, Magnússon KÓ, Jónsson SH. Heilsa og líðan Íslendinga 2012: Framkvæmdaskýrsla. Embætti landlæknis, Reykjavík 2014.

24. Resnick HE, Heineman J, Stone R, Shorr RI. Diabetes in U.S. nursing homes, 2004. Diabetes Care 2008; 31: 287-8.

25. Olafsdottir E, Aspelund T, Sigurdsson G, Benediktsson R, Thorsson B, Harris TB, et al. Similar decline in mortality rate of older persons with and without type 2 diabetes between 1993 and 2004 the Icelandic population-based Reykjavik and AGES-Reykjavik cohort studies. BMC Public Health 2013; 13: 36

26. Benónýsdóttir GE, Árnadóttir SÁ, Halldórsdóttir S. Reynsla aldraðra, sem búsettir eru á eigin heimili, af heilbrigði og af pví hvað viðheldur og eflir heilsu á efri árum. Tímarit hjúkrunarfræðinga 2009; 85: 48-55.

27. Zheng W, McLerran DF, Rolland B, et al. Association between body-mass index and risk of death in more than 1 million Asians. New Engl J Med 2011; 364: 719-29.

28. Garfinkel D, Zur-Gil S, Ben-Israel J. The war against polypharmacy: a new cost-effective geriatric-palliative approach for improving drug therapy in disabled elderly people. Isr Med Assoc J 2007; 9: 430-4.

29. Lau DT, Kasper JD, Potter DE, Lyles A, Bennett RG. Hospitalization and death associated with potentially inappropriate medication prescriptions among elderly nursing home residents. Arch Intern Med 2005; 165: 68-74.

30. Hofbauer LC, Brueck CC, Singh SK, Dobnig H. Osteoporosis in patients with diabetes mellitus. J Bone Miner Res 2007; 22: 1317-28.

31. Shin JH, Scherer Y. Advantages and disadvantages of using MDS data in nursing research. J Gerontol Nurs 2009; 35: 7-17.

ENGLISH SUMMARY

\section{Prevalence of diabetes as well as general health status of Icelandic nursing home residents 2003-2012}

Ingibjorg Hjaltadottir ${ }^{1}$, Arun Sigurdardottir ${ }^{2}$

Introduction: Diabetes is an increasing problem among old people as well as being a contributing factor in their need for institutional care. Comorbidity and use of medication is often greater among people with than without diabetes. The aim of this study was to investigate the prevalence of diabetes in Icelandic nursing homes over the period 2003 2012. Additionally we compared health, functioning, medication use and medical diagnoses of residents with diabetes to those without diabetes, living in nursing homes in 2012.

Material: Retrospective study of 16.169 Minimum Data Set 2.0 assessments, further analysis conducted for data from the year $2012(n=2337)$. Results: Mean age from 82.3 (SD 9.1) to 85.0 years (SD 8.4) and women were $65.5 \%$ to $68.0 \%$. Number of residents with diabetes increased from $10.3 \%$ in the year 2003 to $14.2 \%$ in 2012 ( $p \leq 0,001)$. Mean age of residents with diabetes in the year 2012 was 82.7 compared to 85 years for others. Residents with diabetes had more skin problems, used more medication, their cognitive performance was better and their involvement in activities greater. They were more likely to have hypertension, arteriosclerotic heart disease, stroke, renal failure, manic depressive disorder, diabetic retinopathy or amputation. They were however, less likely to have an anxiety disorder, Alzheimer's disease or osteoporosis. Conclusion: Residents with diabetes are younger than other residents and their cognitive performance is better, their care and treatment may however be complicated and needs to be adapted to each individual. Diabetes is an increasing problem in nursing homes and therefore an area where more knowledge among staff is needed.

'School of Health Sciences, University of Iceland Sæmundargötu 2, 101 Reykjavik and Emergency, Geriatrics, Rehabilitation Services The National University Hospital, 101 Reykjavik, Iceland ${ }^{2}$ School of Health Sciences, University of Akureyri, Nordurslod, 600 Akureyri, Iceland

Key words: Diabetes, geriatric nursing, Minimum Data Set, nursing homes, old people.

Correspondence: Ingibjorg Hjaltadottir, ingihj@hi.is 